\title{
PENGARUH KUALITAS PRODUK DAN STRATEGI PROMOSI TERHADAP KEPUTUSAN MEMBELI CACTUS FLOWER DI JAKARTA SELATAN
}

\author{
Rani \\ ran_rani63@yahoo.co.id \\ Program Studi Magister Manajemen, Universitas BSI \\ Jl. Sekolah Internasional No. 1 - 6 Antapani, Bandung
}

\begin{abstract}
Abstrak: Perkembangan kebutuhan konsumen yang semakin beragam dan persaingan pasar yang semakin ketat membuat Cactus Flower harus mampu bersaing dan memperlihatkan keunggulan dibidang aksesoris seperti gelang dan kalung. Penelitian ini dilakukan bertujuan untuk mengetahui apakah kualitas produk dan strategi promosi penjualan secara simultan dan parsial memiliki pengaruh terhadap keputusan membeli dan manakah yang memiliki pengaruh dominan terhadap keputusan membeli Cactus Flower Jakarta Selatan. Metode yang digunakan yaitu kuantitatif, pengumpulan data kuesioner dan perntayaan skala liker. Populasi dalam penelitian ini adalah konsumen yang membeli Cactus Flower di Jakarta Selatan. Teknik sampling dalam penelitian ini adalah probability sampling. Analisis data menggunakan analisis regresi linear berganda, uji F, uji t, hasil dari regresi linear berganda dengan hasil $\mathrm{Y}=1.202+0,431 \mathrm{X}_{1}+0,180 \mathrm{X}_{2}+\mathrm{e}$ dari persamaan regresi diketahui bahwa kualitas produk memiliki pengaruh yang positif terhadap keputusan membeli. Kualitas produk dan strategi promosi secara simultan terdapat hubungan positif dan signifikan terhadap keputusan membeli. Secara parsial kualitas produk terdapat pengaruh dengan keputusan membeli, sebaliknya strategi promosi tidak berpengaruh dengan keputusan membeli. Apabila kualitas dan strategi promosi ditingkatkan maka akan mengakibatkan keputusan membeli yang tinggi.
\end{abstract}

Kata Kunci: Kualitas produk, strategi promosi dan Keputusan membeli

\begin{abstract}
The development of increasingly diverse consumer needs and increasingly fierce market competition has made Cactus Flower must be able to compete and show excellence in the field of accessories such as bracelets and necklaces. This research was conducted aimed to determine whether product quality and sales promotion strategies simultaneously and partially have an influence on buying decisions and which have the dominant influence on the decision to buy Cactus Flower in South Jakarta. The method used is quantitative, questionnaire data collection and liqueur scale administration. The population in this study were consumers who bought Cactus Flower in South Jakarta. The sampling technique in this study is probability sampling. Data analysis using multiple linear regression analysis, $\mathrm{F}$ test, $\mathrm{t}$ test, the results of multiple linear regression with $\mathrm{Y}=$ $1,202+0,431 \mathrm{X} 1+0,180 \mathrm{X} 2+\mathrm{e}$ results from the regression equation note that product quality has a positive influence on buying decisions. Product quality and promotion strategies simultaneously have a positive and significant relationship to buying decisions.
\end{abstract}


Partially the quality of the product has an influence with the buying decision, on the contrary the promotion strategy does not affect the buying decision. If the quality and promotion strategy is improved, it will lead to high buying decisions.

\section{Keywords: Product quality, promotion strategy and buying decision}

\section{PENDAHULUAN}

Persaingan di dunia perdagangan sangatlah ketat. Apabila adanya globalilasi yang menyebabkan munculnya perdagangan bebas yang membuat dunia seolah tanpa batas. Banyak produsen barang dan jasa dari suatu industri rumahan yang bersaing dengan industri besar untuk menarik minat konsumen di dalam perdagangan.

Untuk menarik minat konsumen membeli produk yang ditawarkan maka dibutuhkan adanya promosi yang efektif, kualitas produk yang bermutu. Menariknya promosi yang ditawarkan akan mempengaruhi minat konsumen untuk mencoba mengkonsumsi produk tersebut. Maka dengan demikian produsen akan terus terpacu untuk membuat ikalan dan promosi yang menarik agar dapat mempengaruhi konsumen untuk membeli produknya. Sedangkan kualitas produk adalah manfaat yang dirasakan oleh konsumen setelah mengkonsumsi produk tersebut. Apabila suatu industri rumahan akan mengeluarkan produk maka sebaiknya harus disesuaikan dengan kebutuhan dan keinginan konsumen. Dengan begitu maka produk tersebut dapat bersaing di pasaran, sehingga menjadikan konsumen memiliki banyak alternatif pilihan produk sebelum pengambilan keputusan untuk membeli suatu produk yang ditawarkan dipasaran.

Cactus Flower adalah produk yang dibuat sendiri untuk menarik konsumen yang sering menghias dirinya dengan kalung dan gelang. Dengan memakai itu semua, tentu saja dapat menunjang gaya penampilan seseorang. Namun, dalam menggunakan aksesoris tersebut masih banyak wanita yang tidak memakai sesuai dengan kebutuhan. untuk meningkatkan penghasilan dan terus berkembang, Cactus Flower membuat strategi promosi di media sosial untuk menjual produknya. Faktor-faktor yang mempengaruhi keputusan membeli adalah kualitas produk dan strategi promosi. Dengan Kualitas yang bagus, meningkatkan strategi promosi maka konsumen akan tertarik untuk melakukan keputusan membeli produk Cactus Flower.

Berdasarkan latar belakang diatas, peneliti menyimpulkan bahwa rumusan masalah yang dapat dikemukakan pada penelitian ini adalah:

1. Apakah ada pengaruh kualitas produk terhadap keputusan membeli

2. Apakah ada pengaruh strategi promosi terhadap keputusan membeli

3. Apakah ada pengaruh secara bersama-sama kualitas produk dan strategi promosi terhadap keputusan membeli 
Berdasarkan latar belakang dan rumusan masalah yang ada, maka penelitian ini dilakukan dengan tujuan:

1. Untuk mengetahui dan menganalisa pengaruh kualitas produk terhadap keputusan membeli

2. Untuk mengetahui dan menganalisa pengaruh strategi promosi terhadap keputusan membeli

3. Untuk mengetahui dan menganalisa secara bersama-sama kualitas produk dan strategi promosi terhadap keputusan membeli

\section{KAJIAN PUSTAKA}

\section{Keputusan Membeli}

Menurut Kotler dan Armstrong (2008: 181), keputusan membeli adalah membeli merek yang palinng disukai, tetapi dua faktor bisa berada antara niat pembelian dan keputusan pembelian. Menurut Suharso (2010: 83), Mengatakan keputusan membeli adalah tahapan dimana membeli telah menentukan pilihannya dan melakukan pembelian produk serta mengkonsumsinya. Menurut Assauri (2004: 141), keputusan membeli adalah suatu proses pengambilan keputusan antara membeli atau tidak melakukan pembelian dan keputusan kegiatan-kegiatan sebelumnya.

Menurut Kotler (2009: 215-252), Keputusan membeli adalah suatu keputusan membeli dari beberapa tahap yaitu, pengenalan masalah, mencari informasi, evaluasi alternatif, keputusan membeli dan perilaku setelah pembelian. Proses pengambilan keputusan dalam pembelian merek suatu produk salah satunya ditentukan oleh perilaku konsumen, proses tersebut merupakan sebuah pendekatan penyesuaian masalah yang terdiri dari lima tahap yang dilakukan konsumen, kelima tahap tersebut adalah pengenalan masalah, pencarian informasi, penilaian alternatif, membuat keputusan, dan perilaku paska pembelian (Kotler, 2004: 224). Dimensi yang mencirikan keputusan pembelian yang digunakan penelitian ini, yaitu:

1. Kebutuhan dan keinginan akan suatu produk

2. Keinginan mencoba

3. Kemantapan akan kualitas suatu produk

4. Keputusan pembelian ulang

\section{Kualitas Produk}

Menurut Kotler dan Amstrong (2008) kualitas adalah karakteristik dari sebuah produk yang memiliki kemampuan untuk memenuhi kebutuhan-kebutuhan yang telah ditentukan dan bersifat laten. Menurut Kotler dan Amstrong (2008: 272), kualitas produk adalah salah satu sarana positioning utama pasar. Kualitas memiliki dampak langsung pada kinerja produk dan jasa. Pride dan Ferrel (2010: 317), Kualitas produk tertuju pada keseluruhan karakteristik dari sebuah produk yang menggambarkan kelebihan produk yang 
diharapkan oleh pembeli untuk memenuhi kebutuhan dan memuaskan pembeli. Menurut Lupioadi (2001: 158), kualitas produk adalah konsumen merasa sangat puas bahwa produk yang mereka gunakan berkualitas. Menurut Kotler dan Amstrong (2004: 347), kualitas produk adalah fungi suatu produk yaitu daya tahan, keandalan, ketepatan, kemudahan operasi dan perbaikan serta atribut bernilai lainnya. Menurut Kotler dan Armstrong (2008: 272) kualitas produk adalah strategi utama pemasaran, karakteristik produk untuk memuaskan kebutuhan pelnggan. Oleh karea itu, kualitas produk berhubungan erat dengan nilai dan kepuasan pelanggan, jika kualitas produk sesuai harapan maka pembeli akan membeli produk tersebut.

Dimensi kualitas produk menurut Fandy Tjiptono (2002:25) mengenukakan, bahwa kualitas produk memiliki beberapa dimensi antara lain :

1. Kinerja (Performance) merupakan karakteristik operasi dan produk inti (core product) yang dibeli.

2. Ciri-ciri atau keistimewaan tambahan (Features) yaitu karakteristik sekunder atau pelengkap.

3. Kesesuaian dengan spesifikasi (Conformance to Spesification) yaitu sejauh mana karakteristik desain dan operasi memenuhi standar yang telah ditetapkan sebelumnya.

4. Keandalan (Realibility) yaitu kemungkinan kecil akan mengalami kerusakan atau gagal pakai.

5. Daya tahan (Durability) berkaitan dengan berapa lama produk tersebut dapat terus digunakan. Dimensi ini mencakup umur teknis maupun umur ekonomis.

6. Estetika (Easthetica) yaitu daya tarik produk terhadap panca indera.

7. Kualitas yang dipersepsikan (Perceived Quality) merupakan persepsi konsumen terhadap keseluruhan kualitas atau keunggulan suatu produk. Biasanya karena kurangnya pengetahuan pembeli akan atribut atau ciri-ciri produk yang akan dibeli, maka pembeli mempersepsikan kualitasnya dari aspek harga, nama merek, iklan, reputasi perusahaan, maupun negara pembuatnya.

8. Dimensi kemudahan perbaikan (Serviceability) meliputi kecepatan, kemudahan, penanganan keluhan yang memuaskan. Pelayanan yang diberikan tidak terbatas hanya sebelum penjualan, tetapi juga selama proses penjualan hingga purna jual yang mencakup pelayanan reparasi dan ketersediaan komponen yang dibutuhkan.

\section{Strategi Promosi}

Menurut Kotler dan G. Armstrong (2010) promosi merupakan aktivitas yang menyampaikan manfaat produk dan membujuk pelanggan untuk membelinya. Menurut Swastha dan Irawan (2008: 349), Promosi adalah "arus informasi atau persuasi satu arah yang dibuat untuk mengarahkan seseorang atau organisasi kepada tindakan menciptakan pertukaran dalam pemasaran".

Menurut Tjiptono (2008: 219), promosi adalah salah satu unsur dari pemasaran yang digunakan untuk memberikan informasi kaitannya tentang suatu produk. Menurut Alam (2007:79), promosi adalah suatu bentuk komunikasi pemasaran untuk menyebarkan 
informasi, mempengaruhi, dan meningkatkan pasar sasaran dan bersedian menerima produknya, membeli dan loyal pada produk yang ditawarkan perusahaan. Dan menurut Swastha dan Irawan (2008: 329), Promosi adalah arus informasi yang dibuat untuk mengarahkan seseorang kepada tindakan menciptakan pertukaran dalam pemsaran.

Promosi yaitu teknik yang digunakan untuk komunikasi dengan para calon pembeli dengan menggunakan media seperti: koran, majalah, televisi, radio, papan nama, poster dan lain-lain, yang tujuannya untuk menarik minat pembeli terhadap suatu produk. Promosi digunakan sebagai sarana untuk menjembatani kepentingan produsen dengan konsumen yang harus benar-benar dipahami oleh seorang manajer. Strategi promosi memiliki tujuan untuk membujuk atau menarik minat pembeli agar tertarik untuk membeli suatu produk. Dimensi yang mencirikan promosi yang digunakan dalam penelitian ini, yaitu:

1. Jangkauan promosi

2. Kuantitas penayangan iklan di media promosi

3. Kualitas penyampaian pesan dalam penayangan iklan di media promosi

\section{Penelitian Yang Relevan}

Agnes Ligia Pratisitia Walukow, Lisbeth Mananeke dan Jantje Sepang (2014) tujuan penelitian ini untuk mengetahui pengaruh kualitas produk, harga, promosi, dan lokasi terhadap kepuan membeli konsumen. Metode penelitian yang digunakan kuantitatif regresi. Hasil penelitian ini secara simultan memiliki pengaruh yang positif dan signifikan terhadap keputusan membeli. Kualitas produk secara parsial memiliki pengaruh yang yang signifikan dan positif terhadap keputusan membeli. Lokasi secara parsial tidak berpengaruh signifikan terhadap keputusan membeli.

Dalam penelitian Lidya Mongi, Lisbeth Mananeke, dan Agusta Repi (2013) tujuan penelitian ini untuk mengetahui kualitas produk, strategi promosi, dan harga pengaruhnya terhadap keputusan pembelian kartu simpati telkomsel di kota Manado. Metode penelitian yang digunakan kuantitatif. Hasil penelitian ini secara simultan kualitas produk, strategi promosi dan harga berpengaruh signifikan terhadap keputusan pembelian kartu simpati telkomsel di kota Manado. Secara parsial kualitas produk, strategi promosi, dan harga berpengaruh signifikan terhadap keputusan pembeli kartu simpati telkomsel di kota Manado. Harga merupakan variabel yang dominan pengaruhnya terhadap keputusan pembelian konsumen terhadap produk kartu simpati.

Krestiawan Wibowo, Handoyo Djoko Waluyo, dan Sari Listyorini (2013) tujuan penelitian ini untuk mengetahui pengaruh kualitas produk, harga, dan promosi terhadap keputusan pembelian permen tolak angin di Semarang. Metode penelitian yang digunakan tipe explanatory research dan teknik pengabilan sampel menggunakan purposive sampling. Kualitas produk, harga, promosi, mempunyai pengaruh terhadap keputusan pembelian. Sedangkan pengaruh kualitas produk, harga, promosi sangat berpengaruh signifikan. 
Bayu Triyanto (2014) tujan penelitian ini untuk mengetahui analisis pengaruh produk, promosi, harga, dan tempat terhadap keputusan pembelian pada toko seyegan sport sleman yogyakarta. Penelitian ini merupakan penelitian korelasional menggunakan metode survei dengan instrumen angket. Hasil penelitian menunjukkan Uji keberartian koefisien tersebut dilakukan dengan cara mengonsultasi harga $F_{\text {hitung }} 13,290>F_{\text {tabel }}(2,58)$ pada taraf signifikansi 5\% dan $\mathrm{Ry}(\mathrm{x} 1 . \mathrm{x} 2 . \mathrm{x} 3 . \mathrm{x} 4)=0,736>\mathrm{R}(0.05)(18)=0,243$, berarti koefisien tersebut signifikan. Dengan demikian hipotesis yang berbunyi "analisis produk, promosi, harga, dan tempat berpengaruh terhadap keputusan pembelian dapat diterima.

Asih Purwanto (2008) tujuan penelitian ini untuk mengetahui pengaruh kualitas produk, promosi dan desain terhadap keputusan pembelian kendaraan bermotor yamaha mio. Metode penelitian yang digunakan kualitatif. Hasil penelitian menunjukan bahwa kualitas produk berpengaruh signifikan terhadap keputusan pembelian, promosi berpengaruh tidak signifikan terhadap keputusan pembelian, dan desain berpengaruh tidak signifikan terhadap keputusan pembelian. Apabila dilakukan penelitian Kualitas produk, promosi, desain secara bersama - sama berpengaruh signifikan terhadap keputusan pembelian.

\section{Kerangka Pemikiran}

Kerangka pemikiran teoritis yang akan dikembangkan pada penelitian ini mengacu pada study literatur yang telah dilakukan. Model penelitian yang akan dikembangkan adalah seperti pada Gambar 1:

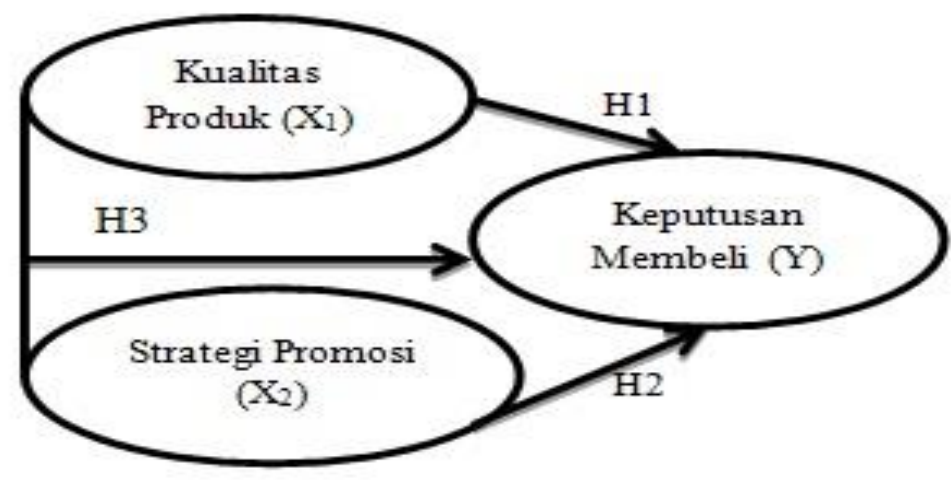

\section{Gambar 1: Kerangka Pemikiran}

\section{Hipotesis Penelitian}

Beberapa hipotesis yang diajukan dalam penelitian ini adalah :

H1 : Di duga kualitas produk berhubungan positif dengan keputusan membeli

H2 : Di duga strategi promosi berhubungan positif dengan keputusan membeli 
H3 : Di duga secara bersama-sama berhubungan positif dengan keputusan membeli

\section{METODE PENELITIAN}

Metode yang digunakan oleh penulis adalah penelitian kuantitatif. Metode pengumpulan data yang digunakan dalam penelitian ini adalah metode angket atau kuesioner. Pengumpulan data dilakukan dengan menggunaka satu macam angket. Pernyataan dalam angket tertutup menggunakan skala liker.

Populasi dalam penelitian ini adalah konsumen yang membeli Cactus Flower di Jakarta Selatan. Teknik sampling dalam penelitian ini adalah probability sampling karena memberi peluang yang sama bagi setiap anggota populasi untuk dipilih menjadi sampel. Analisis data menggunakan analisis regresi linear berganda.

Dalam penelitian ini data yang digunkan adalah data primer yaitu data yang diperoleh langsung dari responden Cactus Flower dengan menggunakan sempel kuesioner yang diberikan kepada 50 responden. Teknik pengumpulan data yang dilakukan dengan kuesioner, wawancara dan observasi. Data sekunder yaitu data yang mendukung data primer. Model yang digunakan dalam penelitian ini adalah model kausalitas atau hubungan pengaruh. Untuk menguji hipotesis yang diajukan dalam penelitian ini maka teknik analisis yang digunakan merupakan analisis data kuantitatif yang tersusun dalam tabel dan perhitungan uji statistika SPSS (statistical Program For Social Science).

\section{HASIL DAN PEMBAHASAN}

\section{Uji Validitas}

Uji validitas dilakukan dengan membandingkan nilai $r$ hitung dengan $r$ tabel untuk degree of freedom $(\mathrm{df})=\mathrm{n}-2$, dalam hal ini adalah jumlah sampel. Jika rhitung $>$ tabel dan nilai positif maka butir atau pernyataan atau indikator tersebut dinyatakan valid (Ghozali, 2011).

Tabel 1. Uji Validitas Variabel Kualitas Produk

\begin{tabular}{|c|c|c|c|}
\hline No Item & r hitung & $\begin{array}{c}r \\
\text { tabel }\end{array}$ & Keterangan \\
\hline Kp1 & 0,530 & 0,284 & Valid \\
\hline Kp2 & 0,565 & 0,284 & Valid \\
\hline Kp3 & 0,526 & 0,284 & Valid \\
\hline Kp4 & 0,664 & 0,284 & Valid \\
\hline Kp5 & 0,689 & 0,284 & Valid \\
\hline
\end{tabular}


Interpretasi tabel menyatakan $\mathrm{kp}$ (kualitas produk) nilai item 1 sampai dengan 5 valid terlihat dari nilai $r$ hitung $>r$ tabel (pada sig. $0,05, n=50, d f=48$ yaitu sebesar 0,284 ).

Tabel 2. Uji Validitas Variabel Strategi Promosi

\begin{tabular}{|c|c|l|l|}
\hline No Item & $\begin{array}{c}\mathrm{r} \\
\text { hitung }\end{array}$ & $\mathrm{r}$ tabel & Keterangan \\
\hline Sp1 & 0,437 & 0,284 & Valid \\
\hline Sp2 & 0,614 & 0,284 & Valid \\
\hline Sp3 & 0,655 & 0,284 & Valid \\
\hline Sp4 & 0,590 & 0,284 & Valid \\
\hline Sp5 & 0,530 & 0,284 & Valid \\
\hline
\end{tabular}

Interpretasi tabel menyatakan Sp (strategi promosi) nilai item 1 sampai dengan 5 valid terlihat dari nilai $r$ hitung $>\mathrm{r}$ tabel (pada sig. $0,05, \mathrm{n}=50, \mathrm{df}=48$ yaitu sebesar 0,284 ).

Tabel 3. Uji Validitas Variabel Keputusan Membeli

\begin{tabular}{|c|c|c|c|}
\hline $\begin{array}{c}\text { No } \\
\text { Item }\end{array}$ & $\begin{array}{c}\mathrm{r} \\
\text { hitung }\end{array}$ & $\begin{array}{c}\mathrm{r} \\
\text { tabel }\end{array}$ & Keterangan \\
\hline $\mathrm{Km} 1$ & 0,683 & 0,284 & Valid \\
\hline $\mathrm{Km} 2$ & 0,660 & 0,284 & Valid \\
\hline $\mathrm{Km} 3$ & 0,712 & 0,284 & Valid \\
\hline $\mathrm{Km} 4$ & 0,608 & 0,284 & Valid \\
\hline $\mathrm{Km} 5$ & 0,489 & 0,284 & Valid \\
\hline
\end{tabular}

Interpretasi tabel menyatakan $\mathrm{Km}$ (keputusan membeli) nilai item 1 sampai dengan 5 valid terlihat dari nilai $r$ hitung $>\mathrm{r}$ tabel (pada sig. $0,05, \mathrm{n}=50, \mathrm{df}=48$ yaitu sebesar 0,284 ).

\section{Uji Reliabilitas}

Reliabilitas mengandung pengertian bahwa sebuah instrumen dapat mengukur sesuatu yang diukur secara konsisten dari waktu ke waktu. Menurut Ghozali (2009), suatu instrumen dikatakan reliabel jika memberikan nilai Cronbach Alpha >0,6. Adapun hasil uji reliabilitas dalam penelitian ini dapat dilihat dalam Tabel 4.4 berikut ini:

Tabel 4. Uji Reliabilitas

\begin{tabular}{|c|c|c|}
\hline Variabel & $\begin{array}{c}\text { Cronbach } \\
\text { Alpha }\end{array}$ & Keterangan \\
\hline Kualitas Produk $\left(\mathrm{X}_{1}\right)$ & 0,731 & Reliabel \\
\hline
\end{tabular}




\begin{tabular}{|l|l|l|}
\hline Strategi Promosi $\left(\mathrm{X}_{2}\right)$ & 0,713 & Reliabel \\
\hline $\begin{array}{l}\text { Keputusan Membeli } \\
(\mathrm{Y})\end{array}$ & 0,749 & Reliabel \\
\hline
\end{tabular}

Hasil uji reliabilitas tersebut menunjukkan bahwa semua variabel memiliki Cronbach Alpha lebih besar dari Standar Alpha yaitu sebesar 0,600 sehingga dapat dikatakan semua konsep pengukur masing-masing variabel dari kuesioner adalah reliabel. Dengan demikian item-item pada masing-masing konsep variabel tersebut layak digunakan sebagai alat ukur.

\section{Uji Asumsi Klasik}

\section{Uji Normalitas}

Pada grafik normal plot, model berdistribusi normal bila titik-titik menyebar di sekitar garis diagonal serta penyebarannya mengikuti arah garis diagonal sebagaimana ditampilkan pada gambar berikut :

Tabel 5. Uji Normalitas

\begin{tabular}{|c|c|c|}
\hline \multicolumn{3}{|c|}{ One-Sample Kolmogorov-Smirnov Test } \\
\hline & & $\begin{array}{l}\text { Unstandar } \\
\text { dized } \\
\text { Predicted } \\
\text { Value }\end{array}$ \\
\hline \multicolumn{2}{|l|}{$\mathrm{N}$} & 50 \\
\hline \multirow[t]{2}{*}{ Normal Parameters ${ }^{\mathrm{a}}$} & Mean & 3.1200000 \\
\hline & $\begin{array}{l}\text { Std. } \\
\text { Deviation }\end{array}$ & .20998310 \\
\hline Most Extreme & Absolute & .077 \\
\hline \multirow[t]{2}{*}{ Differences } & Positive & .053 \\
\hline & Negative & -.077 \\
\hline \multicolumn{2}{|c|}{ Kolmogorov-Smirnov Z } & .546 \\
\hline \multicolumn{2}{|l|}{ Asymp. Sig. (2-tailed) } & .927 \\
\hline
\end{tabular}

a. Test distribution is Normal.

Dari hasil dengan mengunakan cara ini secara keseluruhan (dilihat dari nilai residual) data memiliki distribusi normal, karena memiliki nilai sig diatas alpha 0,05 . 


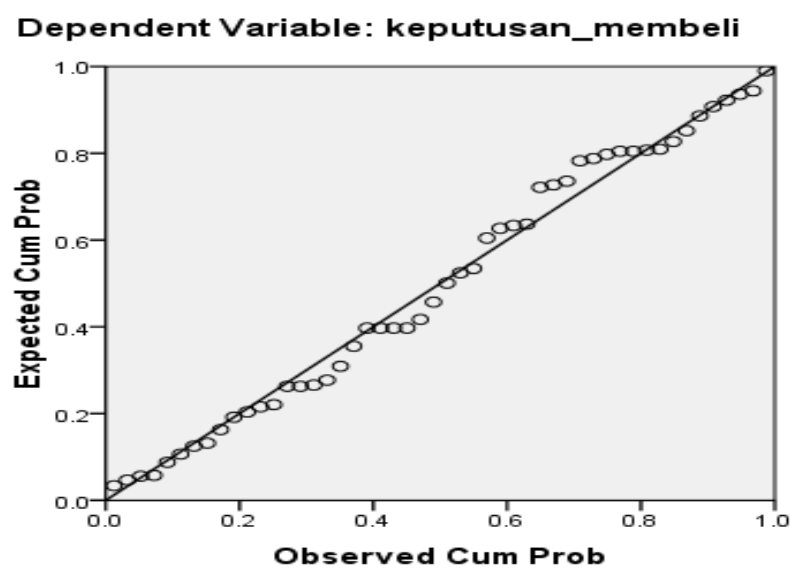

Gambar 2. Uji Normalitas

Hasil pengujian pada grafik normal plot di atas, terlihat bahwa grafik normal plot terlihat menyebar di sekitar garis diagonal, serta penyebarannya mengikuti arah garis diagonal. Hal ini menunjukkan bahwa model regresi layak dipakai karena memenuhi asumsi normalitas.

\section{Uji Multikolinieritas}

Hasil uji multikolinieritas dapat dilihat pada tabel berikut:

Tabel 6. Uji Multikolinearitas

\begin{tabular}{|ll|l|l|}
\hline \multirow{2}{*}{ Model } & \multicolumn{2}{|l|}{ Collinearity Statistics } \\
\cline { 2 - 3 } & Tolerance & VIF \\
\hline 1 & (Constant) & & \\
& kualitas_pr & & \\
oduk & 732 & 1.365 \\
strategi_pr & 732 & 1.365 \\
omosi & .732 & \\
\hline
\end{tabular}

a. Dependent Variable: keputusan_membeli

Dari hasil perhitungan diketahui bahwa tidak ada variabel yang memiliki nilai VIF lebih dari 10 dan nilai Tolerance yang lebih kecil dari 0,10. Hal ini dapat disimpulkan bahwa dalam penelitian ini tidak terdapat korelasi antar variabel independen.

\section{Analisis Regresi Linear Berganda}


Metode analisis regresi linear berganda digunakan untuk mengetahui seberapa besar pengaruh variabel kualitas produk dan strategi promosi terhadap keputusan membeli pada Cactus Flower.

Model regresi linear berganda digunakan untuk menjelaskan hubungan asosiatif dari variabel-variabel bebas terhadap variabel terikat dengan membantu persamaan garis linear berganda yaitu:

$$
Y=a+b_{1} x_{1}+b_{2} x_{2}+\mathrm{e}
$$

Dimana:

$$
\begin{array}{ll}
\mathrm{Y} & =\text { Keputusan Membeli } \\
\mathrm{X}_{1} & =\text { Kualitas Produk } \\
\mathrm{X}_{2} & =\text { Strategi Promosi } \\
\mathrm{a} & =\text { Konstanta } \\
\mathrm{e} & =\text { Error }
\end{array}
$$

\begin{tabular}{|c|c|c|c|c|c|}
\hline \multicolumn{6}{|c|}{ Coefficients $^{\mathrm{a}}$} \\
\hline & \multicolumn{2}{|c|}{$\begin{array}{l}\text { Unstandardize } \\
\text { d Coefficients }\end{array}$} & $\begin{array}{c}\text { Standard } \\
\text { ized } \\
\text { Coefficie } \\
\text { nts }\end{array}$ & & \\
\hline & $\mathrm{B}$ & $\begin{array}{c}\text { Std. } \\
\text { Erro } \\
\text { r }\end{array}$ & Beta & $\mathrm{t}$ & Sig. \\
\hline $1 \quad$ (Constant) & 1.202 & .430 & & 2.793 & .008 \\
\hline kualitas_produk & .431 & .146 & .421 & 2.954 & .005 \\
\hline strategi_promosi & .180 & .132 & .195 & 1.365 & .179 \\
\hline
\end{tabular}

\section{Pengujian Analisis Regresi Berganda}

Analisis regresi berganda ini menggunakan SPSS 16 dengan hasil sebagai berikut :

Tabel 7. Uji Analisis Regresi Berganda

a. Dependent Variable:

keputusan_membeli

Hasil pengolahan data dengan SPSS 16 didapatkan persamaan regresi sebagai berikut:

1. Persamaan regresi berganda $Y=1.202+0,421 X_{1}+0,195 X_{2}+$ e. Dari hasil uji regresi linear berganda tersebut daapat dikatakan bahwa kualitas produk $(42,1 \%)$ dan strategi promosi $(19,5 \%)$. 
2. Kosanta (a) adalah intersep $\mathrm{Y}$ jika $\mathrm{X}=0$, hal ini menunjukana bahwa jika variabel dependen yang digunaka dalam model penelitian akan sebesar konstanta jika variabel independennya $=0$, bedasarkan nilai konstanta $\mathrm{a}=1.202$; artinya jika kualitas produk dan strategi promosinya $=0$, maka keputusan membelinya sebesar 1.202

3. $\mathrm{b}_{1}=0,421$ artinya jika kualitas produk meningkat 1 satuan, maka keputusan membeli meningkat sebesar $42,1 \%$

4. $b_{2}=0,195$ artinya jika strategi promosi meningkat 1 satuan, maka keputusan membeli meningkat sebesar $19,5 \%$.

\section{Uji Simultan (Uji F)}

Uji simultan atau Uji $\mathrm{F}$ digunakan untuk melihat apakah terdapat pengaruh keseluruhan variabel bebas terhadap variabel terikat. Berdasarkan pengolahan data yang dengan menggunakan program SPSS 16 maka dapat dihasilkan output pada tabel sebagai berikut:

Tabel 8. Hasil Uji Simultan (Uji F)

\begin{tabular}{|l|r|r|r|r|r|}
\hline Model & $\begin{array}{c}\text { Sum of } \\
\text { Squares }\end{array}$ & Df & $\begin{array}{c}\text { Mean } \\
\text { Square }\end{array}$ & F & Sig. \\
\hline 1 Regression & 2.161 & 2 & 1.080 & 10.075 & $.000^{\text {a }}$ \\
Residual & 5.039 & 47 & .107 & & \\
Total & 7.200 & 49 & & & \\
\hline
\end{tabular}
a. Predictors: (Constant),
strategi_promosi, kualitas_produk
b. Dependent Variable:
keputusan_membeli

Pengaruh Kualitas Produk dan strategi promosi terhadap Keputusan membeli

Ho: Tidak ada pengaruh secara signifikan secara simultan antara kualitas produk dan strategi promosi dengan keputusan pembelian.

$\mathrm{H}_{1}$ : Ada pengaruh secara signifikan secara simultan antara kualitas produk dan strategi promosi dengan keputusan membeli.

Berdasarkan tabel 2 dapat diketahui bahwa $F_{\text {hitung }}=10.075$ sehingga memenuhi kriteria bahwa jika $F_{\text {hitung }}(10.075)>F_{\text {tabel }}(3,20)$ dan nilai sig. $(0,000)<0,05$. Maka konsekuensinya $\mathrm{H}_{0}$ ditolak $\mathrm{H}_{1}$ diterima. Dengan demikian terbukti bahwa ada pengaruh yang signifikan dari kualitas produk dan strategi promosi secara simultan berpengaruh positif dan signifikan terhadap keputusan membeli. 


\section{Uji Parsial (Uji t)}

Pengujian secara parsial ini dilakukan untuk mengetahui hubungan dari masing masing variabel independen terhadap variabel dependen.

\section{Tabel 9. Hasil Uji Parsial (Uji t)}

\begin{tabular}{|c|c|c|c|c|c|c|}
\hline \multicolumn{7}{|c|}{ Coefficients $^{\mathrm{a}}$} \\
\hline \multirow[b]{2}{*}{ el } & & \multicolumn{2}{|c|}{$\begin{array}{l}\text { Unstandardize } \\
\text { d Coefficients }\end{array}$} & $\begin{array}{c}\text { Standard } \\
\text { ized } \\
\text { Coeffici } \\
\text { ents }\end{array}$ & \multirow[b]{2}{*}{$\mathrm{t}$} & \multirow[b]{2}{*}{ Sig. } \\
\hline & & B & $\begin{array}{l}\text { Std. } \\
\text { Error }\end{array}$ & Beta & & \\
\hline 1 & (Constant) & 1.202 & .430 & & 2.793 & .008 \\
\hline & kualitas_produk & .431 & .146 & .421 & 2.954 & .005 \\
\hline & strategi_promosi & .180 & .132 & .195 & 1.365 & .179 \\
\hline
\end{tabular}

a. Dependent Variable:

keputusan_membeli

Berdasarkan tabel diatas diperoleh hasil sebagai berikut:

1. Pengaruh Kualitas Produk Terhadap Keputusan Membelian

Ho: Tidak ada pengaruh secara signifikan antara kualitas produk dengan keputusan pembelian.

$\mathrm{H}_{1}$ : Ada pengaruh secara signifikan antara kualitas produk dengan keputusan pembelian.

Berdasarkan tabel di atas, diperoleh t hitung untuk variabel kualitas produk sebesar 2.954 dan sig sebesar 0,005. Sedangkan nilai $t$ tabel adalah 1,678. Karena $t$ hitung $>t$ tabel $(2.954>1,678)$ dan nilai sig $<0.05(0.005<0.05)$ maka Ho ditolak, artinya secara parsial terdapat pengaruh signifikan antara kualitas produk dengan keputusan membeli. Sehingga dapat disimpulkan bahwa secara parsial kualitas produk berpengaruh terhadap keputusan membelian.

2. Pengaruh Strategi Promosi Terhadap Keputusan membeli

Ho: Tidak ada pengaruh secara signifikan antara Strategi promosi dengan keputusan membeli. 
$\mathrm{H}_{1}$ : Ada pengaruh secara signifikan antara strategi promosi dengan keputusan membeli.

Berdasarkan data penelitian pada tabel 8, diperoleh t hitung untuk variabel desain produk sebesar 1,365 dan sig sebesar 0,179. Sedangkan nilai t tabel adalah 1,678. Karena $\mathrm{t}$ hitung $>\mathrm{t}$ tabel $(1,365<1,678)$ dan nilai sig $<0.05(0,179>0.05)$ maka Ho diterima, artinya secara parsial tidak terdapat pengaruh signifikan antara strategi promosi dengan keputusan membeli. Sehingga dapat disimpulkan bahwa secara parsial kualitas produk berpengaruh terhadap keputusan pembelian.

\section{Koefisien Determinasi $\left(\mathbf{R}^{2}\right)$}

\section{Tabel 10. Hasil Koefisien Determinasi $\left(\mathbf{R}^{2}\right)$}

\begin{tabular}{|c|c|c|c|c|}
\hline \multicolumn{5}{|c|}{ Model Summary } \\
\hline Model & $\mathrm{R}$ & $\begin{array}{c}\mathrm{R} \\
\text { Square }\end{array}$ & $\begin{array}{l}\text { Adjusted } \\
\text { R Square }\end{array}$ & $\begin{array}{c}\text { Std. } \\
\text { Error of } \\
\text { the } \\
\text { Estimate }\end{array}$ \\
\hline 1 & $.548^{\mathrm{a}}$ & .300 & .270 & 1.637 \\
\hline
\end{tabular}

a. Predictors: (Constant), strategi_promosi, kualitas_produk

b. Dependent Variable: keputusan_membeli

Rumus koefisien determinasi adalah $\mathrm{Kd}=\mathrm{r}^{2}$ x 100\%. Berdasarkan hasil tabel diatas diketahui nilai $\mathrm{r} 2$ adalah 0,270. Maka perhitungan koefisien determinasi adalah sebagai berikut:

$$
\begin{aligned}
\mathrm{Kd} & =0,270 \times 100 \% \\
& =27 \%
\end{aligned}
$$

Berdasarkan perhitungan pada tabel 5, koefisien determinasi nilai yang diperoleh sebesar 27\%. Dari nilai tersebut dapat diartikan bahwa besarnya pengaruh variabel kualitas produk dan strategi promosi dan keputusan membeli adalah $27 \%$, sedangkan sisanya sebesar $73 \%$ di pengaruhi faktor-faktor lain yang tidak diteliti dalam penelitian ini.

\section{PENUTUP}

Berdasarkan pembahasan yang telah dilakukan diatas dapat ditarik kesimpulan bahwa:

1. Dari hasil uji $\mathrm{f}$ dimana nilai $\mathrm{f}_{\text {hitung }}>$ dari tabel $\mathrm{f}_{\text {tabel }}$ menunjukkan bahwa : variabel kualitas produk, dan strategi promosi secara simultan memiliki pengaruh yang signifikan terhadap keputusan membeli (Y).

2. Dari hasil uji $\mathrm{t}$ dimana nilai $\mathrm{t}$ hitung $>$ dari $\mathrm{t}$ tabel menunjukkan bahwa: Variabel kualitas produk (X1) secara parsial memiliki pengaruh yang signifikan terhadap keputusan 
membeli (Y). Variabel Strategi promosi (X2) secara parsil tidak berpengaruh terhadap keputusan membeli (Y).

3. Berdasarkan hasil korelasi yang diperoleh maka dapar disimpulkan bahwa variabel kualitas produk penjualan memiliki hubuangan yang kuat/ dominan dalam mempengaruhi variabel keputusan membeli jika dibendingkan dengan variabel strategi promosi.

4. Bagi peneliti selanjutnya akan lebih baik jika jumlah data yang dimbil lebih banyak sehingga hasil peneliti akan lebih Representative. Semakin bayak data yang diteliti akan semakin baik pula hasil penetapan parameternya. 


\section{DAFTAR PUSTAKA}

Alam, Buchari. (2007). Manajemen Pemasaran dan Pemasaran Jasa. Edisi Revisi. Cetakan kelima. CV Alfabeta: Jakarta

Assauri, Sofjan. (2004). Manajemen Pemasaran. Edisi II. Rajawali Press. Jakarta

Ghozali, Imam. 2009. “Aplikasi Analisis Multivariate dengan Program SPSS “. Semarang : UNDIP.

Ghozali, Imam. 2011. “Aplikasi Analisis Multivariate Dengan Program IBM SPSS 23”. Semarang: Badan Penerbit Universitas Diponegoro

Kotler, Philip (2004). Marketing Management. The Millenium Edition. Englewood Cliffs, New Jersey : Prentice Hall

Kotler dan G. Armstrong. (2004). Prinsip-prinsip Pemasaran. Alih Bahasa oleh Wisnu Chandra Kristiaji. Jilid 2. Edisi 8. Jakarta : Erlangga

Kotler P, dan G. Armstrong. (2008). Prinsip-prinsip pemasaran. Edisi 12, jilid 1. Jakarta : Erlangga

Kotler, Phillip. (2009). Manajemen Pemasaran. Edisi 13. Jakarta : Erlangga

Kotler, Phillip dan Garry Armstrong. 2010. Prinsip-Prinsip Pemasaran, Jilid 1 dan 2 Edisi Kedua Belas. Jakarta : Erlangga

Lupioadi, R. (2001). Manajemen Pemasaran Jasa. Edisi 2. Salemba Empat: Jakarta

Mongi, Lidya.(2013). Kualitas Produk, Strategi Promosi dan Harga Pengaruhnya terhadap Keeputusan Pembelian Kartu Simpati Telkomsel di Kota Manado. Jurnal EMBA, Universitas Sam Ratulangi Manado. Vol.1. No.4. pp 2336 - 2346

Pride, William M. and O.C. Ferrell, 2010. Marketing. Fiftinth Edition. Canada : South Western International Edition

Purwanto, Asih. (2008). Pengaruh Kualitas Produk, Promosi Dan Desain Terhadap Keputusan Pembelian Kendaraan Bermotor Yamaha Mio. Skripsi. Universitas Muhammadia Surakarta

Suharso dan Yudi Sutarso. (2010). Marketing in Practice. Yogyakarta : Graha Ilmu

Swastha, Basu dan Irawan. 2008. Manajemen Pemasaran Modern. Edisi II Yogyakarta: Liberty

Tjiptono, F. (2008). Strategi Pemasaran. Edisi ketiga. Andi: Jakarta

Tjiptono, Fandy. (2002). Strategi Pemasaran. Andy Offset: Yogyakarta

Triyanto, Bayu.(2014). Analisis Pengaruh Produk, Promosi, Harga, Dan Tempat Terhadap Keputusan Pembelian Studi Kasus Pada Toko Seyegan Sport Sleman Yogyakarta. Skripsi. Universitas Negri Yogyakarta

Walukow, dkk. (2014). Pengaruh Kualitas Produk, Harga, Promosi Dan Lokasiterhadap Keputusan Pembelian Konsumen di Bentenan Center Sonder Minahasa. Jurnal. Universitas Sam Ratulangi Manado. Vol.2 No.3. pp. 1737-1749

Wibowo, Krestiawan, dkk.(2013). Pengaruh Kualitas Produksi, Harga dan Promosi Terhadap Keputusan Pembelian Permen Tolat Angin Di semarang. Jurnal. UNDIP. Hal. 1-10 http://ejournal-s1.undip.ac.id/index.php/ 